\title{
Oil Price Volatility, Monetary Policy and Economic Growth in Some Selected Africa Countries
}

\author{
Awopetu, Olayinka Bobola \\ Department of Economics, Afe Babalola University(ABUAD), Ado Ekiti
}

\begin{abstract}
This research work assessed the relationship among oil Price Volatility, Monetary Policy and Economic growth in oil exporting Africa Countries somewhere in the range of 1990 and 2018. Specifically, the investigation looked into the impacts of macroeconomic factors on economic growth and broke down the interrelationships among monetary approach transmission instruments, Oil value stuns and yield development of oil exporting Africa Countries. Information for the investigation was sourced from World Development Indicators distributed by the World Bank, IMF online Database and Central Banks of chosen nations. The investigation employed Westerlund Error Correction Based Panel Cointegration test and Structural Vector Autoregressive (SVAR) as estimation methods. The unit root test resultshowed that the factors of intrigue were coordinated of a similar request that is I(1). Results from SVAR Impulse Response Functions demonstrated that the reaction of yield development to stuns radiating from both financial approach factors and unrefined petroleum cost was sure and huge all through the examination time frame. The outcomes further indicated that expansionary money related strategy that animates a reduction in household loan fee was more viable in expanding the yield development than contractionary monetary formation that motivates an increment local financing cost. It was discovered from the investigation that oil price volatility increase was just prone to modestly affect economic growth while oil price reduction has a huge negative impact on economic growth. This shows that the fall in oil price volatility have deteriorating impact on conversion scale, while oil price increment was seen as unessential to swapping scale development in oil exporting Africa Countries. In light of these discoveries, the analysis in this manner infers that there is deviated relationship among oil price volatility, monetary policy and economic growth in oil exporting Africa Countries.
\end{abstract}

Keywords: Monetary policy, Oil price and Economic growth

DOI: $10.7176 / \mathrm{JESD} / 12-12-09$

Publication date: June $30^{\text {th }} 2021$

\section{Introduction}

Oil price stabilization takes advantage of an important role in economic growth across developed and developing Countries, irrespective of the importance of the economy as a net-importer or net-exporter. Oil-shock effect on economic growth has brought substantial attention in energy economics over the past decades (Olukorede, 2015). Liu, Shi, Wu,Xu, J. (2014) laid emphasy on a different dimension of this importance across different Countries by showing that synergy with monetary policy of the developing Country is required for an effective oil pricing policy for the developing category. This came as a result of the continuous economic declines being experienced in the developing world aftermath of the 1973 oil shock. Oil price, for instance, fell from a peak of \$105 per barrel in 2014 to as low as $\$ 37$ per barrel in 2016, predominantly as a result of the lifting of international sanctions against Iran in 2015, which facilitated an increase in Iranian oil exports, leading to a free fall in crude oil prices (IMF, 2016).The GDP of West Africa's oil-producing Countries has been strongly associated with the oil sector, meaning that the Continent's economy is vulnerable to crude oil price shocks. One of the recent arguments in development economics is the issue of Dutch disease in the resource-rich economies. According toGylfason (2001) 'Members of the Organization of Petroleum Exporting Countries (OPEC) over the past four decades have been experiencing the stunted gross domestic product'. The story is the same in some African oil producing Countries. Nigeria, which is the largest producer of oil in African Countries, had a GDP per capita of US\$2563.10 in 2014 which fell short of the United Nations Year 2014 projected GDP per capita of US\$3222 for Nigeria. Sudan (another Africa oilproducing Country) also had a GDP per- capita of US\$2191.69. However, an outstanding feature of Africans Oil Producing Countries who are net oil exporters is the fact that oil is the mainstay of their economies and oil contributes the largest percentage to their GDP and also provides the highest foreign exchange earnings. For instance, Refined Petroleum which is the main export of Senegal accounts for $\$ 472 \mathrm{M}$ having the top export destinations at Mali, India, Switzerland, China and Spain. In Equatorial Guinea, oil accounts for 80 per cent of total exports and 90 per cent of Govt. revenues. Crude oil production in Equatorial Guinea held 1.1 billion barrels of crude oil reserves as at Jan 2017. Production of petroleum and other liquids averaged 244,000 barrels per day in 2016, which is lower than its peak production of 375,000 barrels per day in 2005. This situation is the same for almost all other African Oil Producing Countries. In Algeria for instance, their oil sector contributes about 46.4 percent to the GDP in 2015 and forms 97percent of the total export earnings.

Another common issue pertaining to the Africa Oil Producing Countries is that the numerous resources 
generated from oil have not been translated to the overall economic development of these economies (World Bank, 2012: IMF, 2010). The prevalence of poverty, unemployment, excessive importation of manufactured goods, decay infrastructures, inadequate power and energy supplies, and low human development index are testimonies to the position of the World Bank and the IMF.

The Nigeria situation is worse because the wealth generated from oil resources has led to increased expenditure and the effect has put further pressure on the prices of manufactured consumer goods (spending effect of "Dutch Disease"). The excessive revenue from oil has by this put further pressure on the real sector of the economy and thereby affecting output performance. However, the degenerating nature of oil reserves of most of the Africa Oil Producing Countries and numerous problems facing them resulted in the stern warning given by the IMF in 2010 that if by the end of the next two decades there are no positive efforts towards diversification of these economies most of them are likely going to run into negative output performance which will lead most of them into economic recession. This situation is evident currently in the Nigerian economy which is the largest oil producer in the Africa Countries. The attendant effect of the fall in oil price is still ravaging the output performance of many African Oil Producing Countries. For instance, some of the oil-producing African Countries are still battling this problem which has resulted in negative output growth.

This study for these reasons contributes to the existing literature by applying Panel model to examine the asymmetric and causal links between monetary Policy, Oil price volatility and Economic growth in some selected African Countries in order to provide a broader insight on how to reduce oil price volatility and boost trade and investment. Additionally, the study intends to establish whether there are significant differences between net oilexporters in the exporting African Countries or not.

\subsection{Literature Review}

\subsection{Theoretical Literature Review}

\subsubsection{Monetary Policy and Output}

The significance of the Monetary Policy in solving the dwindling trend and other myriads of problems confronting the Manufacturing sector and output growth remains the baseline of the Investment Saving Liquidity Money (ISLM) framework which gives the proper analysis and understanding of how monetary policy effects and responses promote output growth. The transmission mechanism is such that changes in monetary policy affect the money supply, which changes the interest rate to balance demand and supply. In turn, interest rate changes affect investment and consumption, which subsequently leads to a change in output and prices. The IS-LM model is deemed to have a major consequence for monetary policy. For instance, when the IS curve is unstable, a money supply target will lead to greater output stability, and when the LM curve is unstable, an interest rate target will produce greater output stability. This helps to elucidate why many central banks abandoned funds targeting in favor of interest rate targeting within the 1970s and 1980s, a period when autonomous shocks to LM were pervasive due to financial innovation, deregulation, and loophole mining. An important implication of this is often that central banks might find it prudent to shift back to targeting monetary aggregates if the IS curve ever again becomes more unstable than the LM curve. Therefore, the proper understanding of this framework should shed light on the channels through which monetary policy directly or indirectly stimulates output growth in the economy. Kutu and Ngalawa (2016) carried out a study on monetary policy shocks and industrial sector performance in South Africa and they found evidence of a symbiotic relationship between industrial output growth and other sectors of the economy that form components of aggregate output. Their finding reveals that the supply shock of money however, is observed to exert a significant positive impact on industrial output growth. In addition to the extension of the IS-LM framework on the monetary policy effects on output growth is the Mundell-Fleming Model with emphasy on a small open economy. This model gives an understanding of monetary policy effects and responses. It portrays the short-run relationship between an economy's nominal exchange rate, interest rate, and output in an open economy in contrast to the IS-LM model, which focuses only on a relationship between the interest rate and output. Whereas, the IS-LM Model deals with an economy under autarky (aclosed economy), the Mundell-Fleming model describes a smallopen economy. The model describes the market for goods and services by adding a new term for net exports. The Mundell-Fleming model argues that an economy cannot simultaneously maintain a fixed exchange rate, free capital movement, and an independent monetary policy. This principle is frequently called the "impossible trinity," "unholy trinity," "irreconcilable trinity, "inconsistent trinity" or the "Mundell-Fleming dilemma."

\subsubsection{Endogenous Growth Theory}

Endogenous growth theory or new growth theory was developed in the 1980s by Paul Romer et al.The main objective of the endogenous growth theory is to make the technological progress an endogenous variable to be explained within the model, hence the name endogenous growth theory. There are many different explanations for technological progress. Most of them, however, have a lot of common characteristics: They are based on constant return to scale for capital. Thus, the Marginal Product of Capital (MPK) is not a decreasing function of capital in these models. They consider technological development as a public good. They focus more on human capital. The 
endogenous growth models introduce the channels through which monetary policy can affect long- growth. Higher savings also leads to higher growth, not just higher GDP per capita. They predict the convergence of GDP per capita between Countries in the long run. This is a consequence of the public good property on technological developments (Barro and Lee 1993). Furthermore, Endogenous growth theory holds that economic growth is primarily the result of the Continent's economy external forces. Endogenous growth theory holds that investment in human capital, innovation, and knowledge are significant contributors to economic growth. The theory also focuses on positive externalities and spillover effects of a knowledge-based economy which can cause economic development. The work of Kenneth Arrow (1962), Hirofumi Uzawa (1965), and Miguel Sidrauski (1967) formed the idea for this research. Paul Romer (1986), Robert Lucas (1988), Sergio Rebelo (1991) and Ortigueira and Santos (1997) omitted technological change instead, growth in these models is as a result indefinite investment in human capital which had a spillover effect on the economy and reduces the diminishing return to capital accumulation.

In the mid-1980s, certaingrowth theorists became increasingly dissatisfied with common accounts of exogenous factors determining long-run growth. They favored a model that replaced the exogenous growth variable (unexplained technical progress) with a model during which the key determinants of growth were explicit in the model. The work of Kenneth Arrow (1962), Hirofumi Uzawa (1965), and Miguel Sidrauski (1967) formed the idea for this research. Paul Romer (1986), Robert Lucas (1988), Sergio Rebelo (1991) and Ortigueira and Santos (1997) omitted technological change instead, growth in these models is as a result of indefinite investment in human capital which had a spillover effect on the economy and reduces the diminishing return to capital accumulation.

\subsubsection{The Monetary Policy Transmission Mechanism (MTM)}

Producing Countries develop a monetary transmission mechanism (MTM) for the Africa Oil Producing Countries. This is a medium through which the objective can be met. The monetary policy transmission mechanism has been identified as a technique through which the dynamics of monetary policy and how it affects growth and other major macroeconomic variables are studied (Ojo and Alege, 2014). The MTM explains various channels through which monetary policy affects growth and also identifies the most potent channel for a particular economy. The following channels are identified in the MTM. The first group of monetary transmission channels is the key monetary policy instruments (MPIs) which comprises of interest rate and money supply. The monetary authorities directly control official interest rates, which determine the interest rates on the money market. This control has implications on the volume of money supply in the economy. For instance, an expansionary monetary policy that is corresponding with a decrease in real interest rates affects aggregate spending in different ways. For example, lower interest rates lead to lower costs of capital, especially important for investment decisions. Consumption expenditures increase, because lower rates favor current consumption over future consumption (saving), called the substitution effect. Interest rates also affect disposable income through interest and dividends receipts and payments, the so-called income effect. The direction and magnitude of the income effect depend on the net asset position of firms and households. This interest rate channel lies at the heart of the traditional Keynesian IS-LM model. (Hicks 1937).

\subsubsection{Exchange Rate Channel}

In open economies, additional real effects of a policy-induced increase in the short-term interest rate pass through the exchange rate channel. For instance, when the domestic nominal interest rate rises above its foreign counterpart, equilibrium in the foreign exchange market requires that the domestic currency gradually depreciate at a rate that serves to be equal to the risk-adjusted returns on various debt instruments. This is the condition of uncovered interest parity. Both in traditional Keynesian models that build on Fleming (1962), Mundell (1963) and Dormbusch (1976) and in the New Keynesian models. This expected future depreciation requires an initial appreciation of the domestic currency that, when prices are slow to adjust, domestically produced commodities becomes more expensive than foreign-produced commodities. Therefore net exports, domestic output, and employment fall. However, it has been identified that oil price volatility is very germane under the exchange rate channels.

\subsection{Empirical Review}

Benramdane (2017) studied the impact of oil price volatility on economic growth in Algeria applying a VAR model using annual data over the period 1970-2012. In his result, it was discovered that the negative effects of oil price volatilityoffset the positive impact of oil boom. It was therefore argued that oil price volatility drives the "resource curse", paradox in Algeria.

Mwabutwa, Viegi and Bittercourt (2016), examined the effectiveness of monetary policy transmission mechanism in Ghana. The study used VAR for the period 2002Q1-2014Q4. It was discovered in the study that monetary policy rate (MPR) is quite effective in signaling the money market interest rates in both the short run and long run, as the effect is incomplete (that is, not one-to-one). The study therefore, supports policies that would promote monetary policy strong financial and macroeconomic stability to help secure effective transmission in Ghana. 
Musa (2015) used quarterly data to analyze the impact of oil price shock on the growth of Nigerian economy over the period of 1970 to 2011 . He discovered from the SVAR using impulse response functions (IRFS) and variance decomposition (VDCs) that response of oil price shocks and unrest to economic growth (RDGP) portrays long run impact on economic growth. The study further revealed that oil price, exchange rate, agricultural output and unrest contained some important information in predicting future path of economic growth in Nigeria.

Gachara (2015), investigated the channels through which oil price shocks affect economic activity in Kenya. The variables used in the study were real exchange, inflation, money supply, real GDP growth and international price of crude oil over the period of 1991 to 2014 using structural vector autoregressive (SVAR) and Granger causality test. It was discovered in the study that there exist a bi-directional causality between real exchange rate and inflation in Kenya. There also exists a unidirectional causality from inflation to real GDP and from real GDP to real exchange rate. The study found that crude oil price shocks have a significant effect on Kenya's macroeconomic performance.

Mutuku and Koech, Osei, (2014), jointly examined the impact of fiscal and monetary policy shocks on some fundamental macroeconomic indicators in three emerging African economies: Ghana, Nigeria and South Africa. The study used vector autoregressive (VAR) method with recursive ordering to explain the relationships between the variables over the years 1970 to 2013. The macroeconomic variables which were considered included real GDP, Inflation and Trade. Granger causality tests were used to determine the causality behaviour among the variables. Orthogonal impulse response functions (IRF) and forecast error variance decompositions were then constructed to identify the effects of both fiscal and monetary policy shocks on the macroeconomic variables. The results showed that the impacts of fiscal policy shocks were more pronounced and significant than monetary policy shocks. Macroeconomic variables were seen to respond considerably to both contractionary and expansionary fiscal policy shocks. Thus, fiscal policy shocks can stimulate economic activity significantly in these Countries. The effects of the monetary policy shocks on the other hand were observed to be long term in nature. Contractionary monetary policy shocks were seen to generally reduce the levels of output.

Shudhasattwa and Pasquale (2015) examined the asymmetric impacts of oil prices on major exporting and importing Countries using three measures such as oil exporters and oil importers external balances: total trade balance, oil balance of trade and non-oil balance of trade. Panel data analysis which covered the periods of 1970 to 1980 was used for this study. It was discovered that the expenditure effect arising from increases in proceeds isfrom oil exports. A reduction in oil prices is found to be beneficial for both total and oil balances in these oil exporting Countries. The result also showed that fall in oil prices have a negative impact on both total and real oil trade balances, resulting from increased oil imports in emerging economies.

Fluoride (2014), examined the effects of oil-price shocks using Norway, and South Africa as case studies between 1980 and 2010. The study employed structural Vector Autoregressive (SVAR) and Panel VAR model. It was discovered from the result that the developed economies stick to the non-linear oil-price shock specifications as argued in the literature. However, these are not feasible within the context of the emerging net-oil importing economy. Furthermore, Structural Vector Autoregressive (SVAR) model decisively restricts the oil-price shock effects while the consequencesintended to be captured may be overruled by the identification restrictions imposed. Nevertheless, the Panel VAR methodology is in a position to accommodate all oil price shock specifications.

\subsection{METHODOLOGY}

\section{Model specification}

The model for this study is taken from the General Framework of the Original Mundell Fleming-Tobin model which was developed by AsbjornRodseth (2000). It is explicitly specified as follows:

$$
G D P_{\text {grit }}=\alpha_{i t}+\alpha_{2} \operatorname{RINTR}_{i t}+\alpha_{3} E X R_{i t}+\alpha_{4} M S_{\text {grit }}+\alpha_{5} G F C F_{i t}+\alpha_{6} I N F_{i t}+\alpha_{7} W O P_{i t}
$$

Where:

GDPgr $=$ Gross Domestic Product growth rate

Rintr $=$ Domestic Real Interest Rate

$\mathrm{EXR}=$ Exchange Rate

$\mathrm{MSgr}=$ Money Supply growth rate $($ Broad $)$

GFCF $=$ Gross Fixed Capital Formation $\{$ which captures Capital $(\mathrm{K})\}$

$\mathrm{INF}=$ Inflation Rate

$\mathrm{WOP}=$ World Oil Price

$\alpha_{1}$ is a constant.

$\alpha_{2,} \alpha_{3}, \alpha_{4}, \alpha_{5}, \alpha_{6}$, and $\alpha_{7}$ are parameters attached to the explanatory variables.

it stands for time trend.

\section{Estimation Techniques}

In a bid to achieve the specific objectives stated in this study, the two most prominent econometric techniques 
were employed, namely: Westerlund (2007) Panel Cointegration method and Panel Structural Vector AutoRegressive (P-SVAR) techniques.

\section{Sources of Data}

The data to be used for this study is Secondary data which was sourced from World Bank Development Indicator, World Bank Data Base, and Central Bank of various African Countries (2019).

The data used for this model are time series data which spans from 1990 to 2018.

\subsection{Discussion of Results}

\subsection{Results of the Panel Unit Root Tests}

The method of panel unit root test adopted for this study is Augmented-Dickey Fuller (ADF) test. The test has been proven to be suitable in verifying stationarity, comparison and clarification in panel data.

Table 4.1 Augmented Dickey Fuller Unit Root Test at First Difference (1990-2018)

\begin{tabular}{|l|l|l|l|l|}
\hline Variable & ADF Test Statistic & $95 \%$ Critical ADF Value & P-value & Remark \\
\hline EXR & -12.47619 & -3.468521 & $0.0000^{* * *}$ & Stationary \\
\hline GDPGR & -13.39092 & -2.878311 & $0.0000^{* * *}$ & Stationary \\
\hline GFCF & -8.690833 & -2.879155 & $0.0000^{* * *}$ & Stationary \\
\hline INF & -11.71024 & -2.878515 & $0.0000^{* * *}$ & Stationary \\
\hline MSGR & -12.61991 & -2.878212 & $0.0000^{* * *}$ & Stationary \\
\hline RINTR & -11.23812 & -2.878413 & $0.0000^{* * *}$ & Stationary \\
\hline WOP & -17.14692 & -2.878212 & $0.0000^{* * *}$ & Stationary \\
\hline
\end{tabular}

Source: Author's Computation, (2020)

The results in Table 4.1 showed that at $1 \%$ level of significance, all the variables are not stationary at their levels but are made stationary at their first difference. This implies that all the variables are integrated of order one, 1(1). In this regard, the economic implication of stationary variables is that any disturbance or shock will not be sustained for a long period of time, that is, volatility to the variables will vanish over time.

Table 4.2 Vector Error correction Model

\begin{tabular}{|c|c|c|}
\hline CointegratingEq: & CointEq1 & \\
\hline GDPGR(-1) & 1.000000 & \\
\hline $\operatorname{EXR}(-1)$ & 0.000185 & \\
\hline & $(0.00025)$ & \\
\hline & {$[0.74404]$} & \\
\hline $\mathrm{C}$ & -4.140026 & \\
\hline Error Correction: & $\mathrm{D}$ (GDPGR) & $\mathrm{D}(\mathrm{FXR})$ \\
\hline CointEq1 & -0.515293 & -55.21655 \\
\hline & $(0.09402)$ & $(22.0023)$ \\
\hline & {$[-5.48057]$} & {$[-2.50958]$} \\
\hline $\mathrm{D}(\operatorname{GDPGR}(-1))$ & -0.099295 & 62.15758 \\
\hline & $(0.09330)$ & (21.8326) \\
\hline & [-1.06429] & [2.84700] \\
\hline $\mathrm{D}($ GDPGR(-2)) & -0.048033 & 34.00169 \\
\hline & $(0.07867)$ & (18.4102) \\
\hline & {$[-0.61056]$} & [ 1.84689$]$ \\
\hline $\mathrm{D}(\operatorname{EXR}(-1))$ & 0.000255 & 0.015820 \\
\hline & $(0.00033)$ & $(0.07687)$ \\
\hline & [0.77488] & [0.20580] \\
\hline $\mathrm{D}(\operatorname{EXR}(-2))$ & 0.000359 & 0.009774 \\
\hline
\end{tabular}




\begin{tabular}{|c|c|c|}
\hline & $(0.00033)$ & $(0.07609)$ \\
\hline & [1.10493] & {$[0.12845]$} \\
\hline \multirow[t]{3}{*}{$\mathrm{C}$} & 0.009496 & -0.037784 \\
\hline & $(0.22813)$ & $(53.3848)$ \\
\hline & {$[0.04162]$} & {$[-0.00071]$} \\
\hline \multirow[t]{3}{*}{ D(GFCF) } & 0.013964 & -0.067351 \\
\hline & $(0.00610)$ & $(1.42829)$ \\
\hline & [2.28796] & {$[-0.04716]$} \\
\hline \multirow[t]{3}{*}{ D(INF) } & -0.037083 & 12.16879 \\
\hline & $(0.02677)$ & $(6.26370)$ \\
\hline & {$[-1.38542]$} & [1.94275] \\
\hline \multirow{3}{*}{ D(MSGR) } & -0.056262 & 43.36902 \\
\hline & $(0.06396)$ & $(14.9686)$ \\
\hline & {$[-0.87958]$} & [2.89734] \\
\hline \multirow[t]{3}{*}{ D(RINTR) } & -0.003278 & -3.649146 \\
\hline & $(0.02297)$ & (5.37630) \\
\hline & {$[-0.14269]$} & {$[-0.67875]$} \\
\hline \multirow{3}{*}{$\mathrm{D}(\mathrm{WOP})$} & 1.354719 & -286.2182 \\
\hline & $(1.27116)$ & $(297.468)$ \\
\hline & [1.06573] & {$[-0.96218]$} \\
\hline R-squared & 0.336012 & 0.111044 \\
\hline Adj. R-squared & 0.294512 & 0.055484 \\
\hline Sum sq. resids & 1419.295 & 77723462 \\
\hline S.E. equation & 2.978354 & 696.9732 \\
\hline F-statistic & 8.096810 & 1.998636 \\
\hline Log likelihood & -423.5780 & -1356.447 \\
\hline Akaike AIC & 5.082784 & 15.99354 \\
\hline Schwarz SC & 5.284879 & 16.19563 \\
\hline Mean dependent & 0.017958 & 3.148651 \\
\hline S.D. dependent & 3.545942 & 717.1523 \\
\hline
\end{tabular}

Source: Author's Computation, (2020)

The upper column of Table 4.2 explains the breakdown of error correction term which is earlier modeled as: $\mathrm{ECT}_{\mathrm{t}-1}=\left[\mathrm{Y}_{\mathrm{t}-1-\mathrm{Nj}}-\mathrm{X}_{\mathrm{t}-1}\right]$

Where ECT represents the Error correction term, $\mathrm{Y}_{\mathrm{t}-1}$ represents the Equation of interest and $\mathrm{Nj} \mathrm{X}_{\mathrm{t}-1}$ represents the other endogenous variable.

The equation above is the co integration equation and long run model. From the result, the long run model is thereby shown:

$\mathrm{ECT}=1.000 \mathrm{GDPGR}_{\mathrm{t}-1}+0.00018 \mathrm{EXR}_{\mathrm{t}-1}-4.140026$.

The GDPGR $\mathrm{t}_{\mathrm{t}-1}$ is the equation of interest while $\mathrm{EXR}_{\mathrm{t}-1}$ is the other endogenous variable. This represents the cointegration equation and the error correction model signifying long run relationship.

The lower part of Table 4.2 represents short run coefficient with two different target variables which are GDPGR and EXR. For the GDP, the result is as follows:

GDPGR $_{\mathrm{t}}=-0.5152 \mathrm{ECT}_{\mathrm{t}-1}-0.099 \mathrm{GDPGR}_{\mathrm{t}-1}-0.048 \mathrm{GDPGR}_{\mathrm{t}-2}+0.00026 \mathrm{EXR}_{\mathrm{t}-1}+0.00036 \mathrm{EXR}_{\mathrm{t}-2}+0.009$

The adjustment coefficient is negative and it is interpreted as the previous period deviation from the equation which is corrected in the current period with the adjustment speed of $51.5 \%$.

The result shows that a $1 \%$ change in GDPGR for 1 period and 2 period lags will lead to a decrease in the GDPGR G $_{\mathrm{t}}$ to a tune of -0.99 and -0.05 respectively.

The result for the EXR shows that a percentage change in EXR for 1 period and 2 period lags will lead to an increase in $\mathrm{GDPGR}_{\mathrm{t}}$ to the tune of 0.003 and 0.0004 respectively. This simply shows a positive relationship between Economic Growth and Exchange Rate. 
For the second target variable which is exchange rate, the result from Table 4.5 is written as follows: $\mathrm{EXR}_{\mathrm{t}}=-55.217 \mathrm{ECT}_{\mathrm{t}-1}+62.16 \mathrm{GDPGR}_{\mathrm{t}-1}+34.002 \mathrm{GDPGR}_{\mathrm{t}-2}+0.0158 \mathrm{EXR}_{\mathrm{t}-1}+0.009774 \mathrm{EXR}_{\mathrm{t}-2}-0.038$.

The result shows that a percentage change in GDP for 1 period and 2 period lags will increase the EXR to the tune of 62.16 and 34.002 respectively.

The result for the EXR shows that a percentage change in EXR for 1 period and 2 period lags will lead to an increase in $\mathrm{EXR}_{\mathrm{t}}$ to the tune of 0.0158 and 0.0098 respectively. This also shows a positive relationship between economic growth and exchange rate.

\subsection{Results of the Panel Unit Root Tests}

The method of panel unit root test adopted for this study is Augmented-Dickey Fuller (ADF) test. The test has been proven to be suitable in verifying stationarity, comparison and clarification in panel data.

Table 4.4.1 Augmented Dickey Fuller Unit Root Test at First Difference (1990-2018)

\begin{tabular}{|l|l|l|l|l|}
\hline Variable & ADF Test Statistic & $95 \%$ Critical ADF Value & P-value & Remark \\
\hline EXR & -12.47619 & -3.468521 & $0.0000^{* * *}$ & Stationary \\
\hline GDPGR & -13.39092 & -2.878311 & $0.0000^{* * *}$ & Stationary \\
\hline GFCF & -8.690833 & -2.879155 & $0.0000^{* * *}$ & Stationary \\
\hline INF & -11.71024 & -2.878515 & $0.0000^{* * *}$ & Stationary \\
\hline MSGR & -12.61991 & -2.878212 & $0.0000^{* * *}$ & Stationary \\
\hline RINTR & -11.23812 & -2.878413 & $0.0000^{* * *}$ & Stationary \\
\hline WOP & -17.14692 & -2.878212 & $0.0000^{* * *}$ & Stationary \\
\hline
\end{tabular}

Source: Author's Computation, (2020)

The results in Table 4.3 showed that at $1 \%$ level of significance, all the variables are not stationary at their levels but are made stationary at their first difference. This implies that all the variables are integrated of order one, 1(1). In this regard, the economic implication of stationary variables is that any disturbance or shock will not be sustained for a long period of time, that is, volatility to the variables will vanish over time.

4.4 The pairwise causality test

\begin{tabular}{|c|c|c|c|c|}
\hline Null Hypothesis: & Obs & F-Statistic & Prob. & Result \\
\hline GDPGR does not Granger Cause EXR & 172 & 1.61874 & 0.2012 & \multirow[b]{2}{*}{ Independence causality } \\
\hline \multicolumn{2}{|l|}{ EXR does not Granger Cause GDPGR } & 0.10289 & 0.9023 & \\
\hline GFCF does not Granger Cause EXR & 172 & 444579 & 00131 & \multirow{2}{*}{$\begin{array}{l}\text { Unidirectional } \\
\text { relationship }\end{array}$} \\
\hline \multicolumn{2}{|l|}{ EXR does not Granger Cause GFCF } & 1.51997 & 0.2217 & \\
\hline INF does not Granger Cause EXR & 172 & 008258 & lo 9208 & \multirow[b]{2}{*}{ Independence causality } \\
\hline \multicolumn{2}{|l|}{ EXR does not Granger Cause INF } & 0.58070 & 0.5606 & \\
\hline MSGR does not Granger Cause EXR & 172 & 0.31635 & 0.7292 & \multirow[b]{2}{*}{ Independence causality } \\
\hline \multicolumn{2}{|l|}{ EXR does not Granger Cause MSGR } & 0.43218 & 0.6498 & \\
\hline RINTR does not Granger Cause EXR & 172 & 232513 & 0.1009 & \multirow[b]{2}{*}{ Independence causality } \\
\hline \multicolumn{2}{|l|}{ EXR does not Granger Cause RINTR } & 0.45805 & 0.6333 & \\
\hline WOP does not Granger Cause EXR & 172 & 0.94805 & 0.3896 & \multirow[b]{2}{*}{ Independence causality } \\
\hline \multicolumn{2}{|l|}{ EXR does not Granger Cause WOP } & 1.17555 & 0.3112 & \\
\hline GFCF does not Granger Cause GDPGR & 172 & 0.78482 & 0.4579 & \multirow[b]{2}{*}{ Independence causality } \\
\hline \multicolumn{2}{|l|}{ GDPGR does not Granger Cause GFCF } & 1.33910 & 0.2649 & \\
\hline INF does not Granger Cause GDPGR & 172 & 0.31915 & 0.7272 & \multirow[b]{2}{*}{ Independence causality } \\
\hline \multicolumn{2}{|l|}{ GDPGR does not Granger Cause INF } & 1.01686 & 0.3640 & \\
\hline MSGR does not Granger Cause GDPGR & 172 & 4.10899 & 0.0181 & \multirow{2}{*}{$\begin{array}{l}\text { Unidirectional } \\
\text { relationship }\end{array}$} \\
\hline \multicolumn{2}{|l|}{ GDPGR does not Granger Cause MSGR } & 0.10431 & 0.9010 & \\
\hline RINTR does not Granger Cause GDPGR & 172 & 0.53016 & 0.5895 & Independence Causality \\
\hline
\end{tabular}




\begin{tabular}{|c|c|c|c|c|}
\hline \multicolumn{2}{|l|}{ GDPGR does not Granger Cause RINTR } & 0.07497 & 0.9278 & \\
\hline WOP does not Granger Cause GDPGR & 172 & 1.34309 & 0.2638 & \\
\hline \multicolumn{2}{|l|}{ GDPGR does not Granger Cause WOP } & 0.34034 & 0.7120 & Independence Causality \\
\hline INF does not Granger Cause GFCF & 172 & 0.62972 & 0.5340 & \\
\hline \multicolumn{2}{|l|}{ GFCF does not Granger Cause INF } & 0.02154 & 0.9787 & Independence Causality \\
\hline MSGR does not Granger Cause GFCF & 172 & 0.32782 & 0.7210 & \\
\hline \multicolumn{2}{|l|}{ GFCF does not Granger Cause MSGR } & 0.08931 & 0.9146 & Independence Causality \\
\hline RINTR does not Granger Cause GFCF & 172 & 2.08747 & 0.1272 & \\
\hline \multicolumn{2}{|l|}{ GFCF does not Granger Cause RINTR } & 0.47623 & 0.6220 & Independence Causality \\
\hline WOP does not Granger Cause GFCF & 172 & 2.25027 & 0.1086 & \\
\hline \multicolumn{2}{|l|}{ GFCF does not Granger Cause WOP } & 0.96138 & 0.3845 & Independence Causality \\
\hline MSGR does not Granger Cause INF & 172 & 2.74994 & 0.0668 & \\
\hline \multicolumn{2}{|l|}{ INF does not Granger Cause MSGR } & 1.57534 & 0.2100 & Independence Causality \\
\hline RINTR does not Granger Cause INF & 172 & 0.20104 & 0.8181 & Unidirectional \\
\hline \multicolumn{2}{|l|}{ INF does not Granger Cause RINTR } & 3.43288 & 0.0346 & Relationship \\
\hline WOP does not Granger Cause INF & 172 & 6.08864 & 0.0028 & Unidirectional \\
\hline \multicolumn{2}{|l|}{ INF does not Granger Cause WOP } & 0.63633 & 0.5305 & Relationship \\
\hline RINTR does not Granger Cause MSGR & 172 & 0.63014 & 0.5338 & Unidirectional \\
\hline \multicolumn{2}{|l|}{ MSGR does not Granger Cause RINTR } & 4.13103 & 0.0177 & Relationship \\
\hline WOP does not Granger Cause MSGR & 172 & 1.17283 & 0.3120 & \\
\hline \multicolumn{2}{|l|}{ MSGR does not Granger Cause WOP } & 0.99076 & 0.3735 & Independence Causality \\
\hline WOP does not Granger Cause RINTR & 172 & 0.47659 & 0.6217 & \\
\hline \multicolumn{2}{|l|}{ RINTR does not Granger Cause WOP } & 1.31306 & 0.2718 & Independence Causality \\
\hline
\end{tabular}

Source: Author's Computation, (2020)

The first result shows independence causality between GDPRGR and EXR which explains that increase in EXR does not cause changes in GDPRGR during the period under review. This is evident in the fact that both GDPRGR and EXR data were increasing simultaneously without recourse to each other.

The second result shows a unidirectional causality between GFCF and EXR. This means that the rising GFCF did Granger cause increase in EXR i.e. increase in GFCF causes a reduction in exchange rate but increase in EXR did not cause any changes to GFCF.

The third result shows independence causality between INF and EXR. This explains that increase in EXR does not cause changes in INF during the period under review. This is evident in the fact that both INF and EXR data were increasing simultaneously without recourse to each other.

The result between MSGR and GDPGR shows that there is unidirectional causality between the two variables which explains that rising MSGR did granger cause increase in GDPGR. i.e. increase in MSGR causes a change in GDPGR during the period.

\subsection{CONCLUSION AND RECOMMENDATION}

\subsection{Conclusion}

Based on the assessment of the relationship among oil price volatility, monetary policy indicators and output growth in the oil exporting African Countries, it is concluded according to the results and discussion of findings that the macroeconomic variables selected for this study appeared to determine and predict economic growth both in the long-run and short run. It is also observed that no exchange rate system is best and no one is bad for African oil exporting Countries judging from the costs and benefits the exchange rate system exerted on these Countries. In addition, based on the results of the SVAR impulse response function in this research work, it is therefore concluded that expansionary monetary policy is more effective in compensating and offsetting the negative effect of the decline in oil price in the African oil exporting Countries and that the economies of oil exporting 
AfricanCountries are prone to the volatility of oil price from the real interest rate.

\subsection{Policy Recommendations}

1. Diversification into non- oil sources of energy which include renewable energy such as solar, hydro, wind e.t.c

2. Implementation of expansionary monetary policies that will stabilize their exchange rate and boost trade and investment.

3. Diversification from over reliance on oil to other sectors such as the manufacturing sector and agricultural sector so as to reduce the effect of uncertainties in the economy.

\section{REFERENCES}

Aliyu, S.U.R. (2009). Oil price shocks and the Macro Economy in Nigeria: A Non linear Approach. MPRA paper No 18726.

Amir M.T and Mohammed A (2017): Oil price Volatility and its impact on Economic Growth in Pakistan :Journal of Finance and Economics vol 1

Apere O.\&ljomah, A. M. (2013). Macroeconomic impact of oil price levels and volatility in Nigeria. International Journal of Academic Research in Economics and Management Sciences, 24), 15-25.

Asbjorn, R. (2000). Open economy macroeconomics. Cambridge University Press.

Amuzegar, A. (2001). OPEC as Open.Journal of Foreign Affairs. 77(6), 95-129

Bailliu, J., Lafrance, R. \& Perrault J.F. (2003). Does exchange rate policy matter for growth? Internationafonance, 6(3), 381-414

Balke, N. S., Brown., S. A.\&Yücel, M. K (2002). Oil price shocks and the U.S. economy: where does the Asymmetry Originate? The energy journal, 23(3), 363-394

Barro, R \& Lee.J. (1993).Intenational comparisons of educational attainment.Journal of Monetary Economics, 32 (3), 363-394

Barsky, R. B., \&Kilian, L. (2004).Oil and the macroeconomy since the 1970s.Journal of Economic Perspectives, $18(4), 115-134$

Bhattacharya, R \&Ghura, D. (2006).Oil and growth in the republic of Congo.IMF working papers, 06(185), 3467.

Becklemans, L (2005). Credit and monetary policy: An Australian SVAR. Reserve Bank of Australia Research Discussion Paper Series, (1), 2-9

Bermanke.B S (1986). Alternative explanations of the money-income correlation Carnegie Rochester Conference Series on Public Policy, (25), 49-100

Bemanke, B. S.\& Binder, A. S. (1992). The federal funds rate and the channels of monetary transmission. The American Economic Review, 901-921

Benramdane, A. (2017). Oil price volatility and economic growth in Algeria. Energy Sources, Part B. Economics, Planning, and Policy. 12(4), 338-343

Bernanke, B.S., Gertler, M. \&Watson, M.(1997). Systematic monetary policy and the effects of oil price shocks. Brookings Papers on Economic Activity, 1997(1), 91-157

Berumen, H. (2009). Measuring monetary policy for a small open economy: Turkey, Joumal of Macroeconomic, 29(7), 411-430

Berument H.\&Dincer. N. (2004).Effects of exchange rate risk on economic performance in Turkey. Applied Economics, 36(23), 2429-2441

Bhattacharya, R. \&Ghura.D. (2006). Oil and growth in the republic of Congo: IMF Working papers: 06/185

Bjemland, H. C. (2009). Oil price shocks and stock market booms in an oil exporting Country. Scottish Journal of Political Economy.

Blundell, R. \& Bond, S. (1998). Initial conditions and moment restrictions in dynamic panel data models. Journal of Econometrics.

Brischetto, A, \& Voss, G. (1999).A structural vector autoregression model of monetary policy in Australia. Economic Research Department, Reserve Bank of Australia

Brown and Yucel (2002).Energy prices and aggregate economic activity. An interpretative survey. Article in the Quarterly Review of Economics and Finance 42(2): 193-208

Chaudhuri, K. (2000), Long run prices of primary commodities and oil prices. Working Papers: The University of Sydney

Cheng. M. K. (2006). A VAR Analysis of Kenya's Monetary Policy Transmission Mechanism: How does the Financial Institution REPO Rate Affect the Economy? International Monetary fund

Chipote and Markehtha (2014). The great plunge in oil prices: Causes, consequences, and policy Responses: Policy Research

Cunado, J., Perez de Gracia, F. (2005). Oil prices, economic activity and inflation: Evidence for some Asian Countries. The Quarterly Review of Economics and Finance, 45, 65-83 
Demachi, K. (2012), Effects of crude oil valatility and changes on the Nigerian economy, MPRA paper No. 41413

Easterly, W Robelo, S (1993).fiscalpolicy and economic growth: An empirical investigation. Journal of Monetary Economies, (32), 417-458,

Engel, R Granger, C.W (1987), Cointegration and error Correction

Elbourne, A. (2008) The United Kingdom housing market and the Monetary Policy transmission mechanism: An SVAR approach, Journal of Housing Economics, 170), 65-87

Elboume A de Haan, J. (2006).Financial structure and monetary policy transmission in transition Countries.Journal of Comparative Economies, 34(1), I-23

Elijah, U. \& Festus O, E, (2008).Exchange rate volatility, inflation uncertainty and foreign direct Investment in Nigeria.Botswana Journal of Economics, 5(7), 14-31.

Enoch and Nicholas (2018): Monetary Policy and Economic growth. London Journal of Research in Management and Business. Vol 19

Fenderer, J. P. (1996), Oil price volatility and the macro economy Journal of Macroeconomics 18 1, winter, 1-26

Francois, L\& Mignon,V,(2008). Influence of oil price on economic activities and other macroeconomic and financial variables. CEPI Working Papers, 2008(5), 12-34

Franz, E. (2009). Dynamic panel data methods for Cross-Section panels. Vienna, Australia

Flouride (2014). Recent volatility in the price of crude oil. Journal Energy Sources, Part B: Economics, Planning, and policy. Volume 12,2017 - issue 5

Gachara (2015). Transmission Channels of crude oil price shocks on Kenya's Economy: A Research Project submitted to the Department of Economic Theory in Partial.

Gali, J. \&Gartler, M. (1998). Monetary policy and exchange rate volatility in a small open economy.Review of Economic Studies, (72), 707-734. Garcia, C. \& N. Malet (2007).

Gajarati, S. N. (2007). Basic Econometrics.Me Graw-Hill, Singapore.

Gounder and Bartlett (2007): Macro economic effects of world oil food price shocks in Asia And Pacific economies: application of SVAR models. Article in OPEC Energy Review 37(3): Gylfson, T. (2000), Fix or flex? Alterative exchange rate regimes in an Era of global Capital development. EuropeanEconomic Review, (45) 847-59.

Habib, M.\&Kalamova, M (2007), Are there oil Currencies? The real exchange rate of oil Exporting Countries, in European Central Bank working paper 839

Hadian, E.,Parsa, H. (2006), the effects of oil price fluctuation on the macroeconomic Performance in Iran.Journal of Humanities and Social Sciences, 6(22),111-132.

Hamilton, J.D. (1996), this is what happened to the oil price-macroeconomic relationship, Journal of Monetary Economics. (38), 215-220

Hamilton, J. D. (2005). Oil and the macroeconomy. Prepared for Palgrave Dictionary of Economics, Department of Economics, 0508 University of California, San Diego La Jolla

Hamilton, J. D. (2000), what is oil shock?NBER Working Paper 7755.

Hooker, M.A. (1996), what happened to the oil price-macro economy relationship? Journal of Monetary Economics(38), 195-213

Hung, R. D., Masulis, R. W. \& Stoll, H. R. (1996), Energy shocks and financial markets, Journal of Futures Markets, (16), 1-27.

IMF. (2016). International Monetary Fund economic report: Africa focus. Special, (47), 13-28.

Irfan, H. \& Ume, A. (2011).Impact of monetary policy on gross domestic product (GDP) of Pakistan. /Interdisciplinary Journal of Contemporary Research in Business, 3(1), 1348- 1361

Iwayemi, A., Fowowe, B (2011), Impact of oil price shocks on selected macroeconomic variables in Nigeria. Energy Policy, 39(2), 603-612.

Jimenez - Rodriguez, R., Sanchez, M. (2005). Oil price shocks and real GDP growth: Empirical evidence for some OECD Countries. Applied Economics, 37, 201-228

Jones, C. M. \&Kaul, G. (1996), Oil and the stock markets, The Journal of Finance, 2.

John Baffes, A. AyhanKose, FransiscaOhnsorge, and Marc Stocker (2016): The impact of oil Prices on the Economic Growth and Development in the MENA Countries. paper No 89073.

Joseph and Festus (2013): Oil price Volatility and Macro economy, International of Energy Economics and Policy $3(2): 143-152$

Musa (2015): Crude oil price and Exchange Rate on Economic Growth. Open Access Library Journal

Mutuku, B. and Koech, C.(2014): 'Monetary Policy, Fiscal Policy and Economic Growth in Emerging African Economies",

Nwabutta, Viegi and Bitter Court (2016). Current drop in Oil Prices: Impact on Africa international Association for Energy Economics.

Sudhasattwa and Pasquale (2015): “Asymmetric oil shocks and external balances of Major oil exporting and importing Countries”. Energy Economics, Elsevier, Vol. 56(c), pages 42-50 